\title{
Instrumen Tes Diagnostik Konsepsi Lima Tingkat pada Materi Gerak Lurus: Pengembangan, Uji Validitas dan Reliabilitas serta Uji Coba Terbatas
}

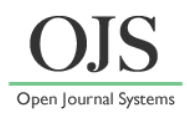

\author{
Indah P.M. Sari, Frida U. Ermawati* \\ Jurusan Fisika, FMIPA, Universitas Negeri Surabaya (UNESA), Surabaya 60231 Indonesia \\ *E-mail: frida.ermawati@unesa.ac.id
}

DOI: https://doi.org/10.33369/pendipa.5.2.152-162

\begin{abstract}
[Five-Tier Diagnostic Test Instrument in Straight Motion Concepts: Development, Validity and Reliability Test and the Limited Trials] Physics lesson is difficult for high school students to understand, including the Straight Motion Concepts. For example, students assumed a pen that was dropped on the floor is an example of free fall motion. According to Physics concept, in free fall motion, a moving object is only affected by the grafity force and the object is in unbalanced condition. Meanwhile, when a pen was dropped, the force that affects not only the gravitational force, but also the force from the student's hand. The mismatch between students' assumptions and the Physics concept shows that students experience what is called a misconception. Such misconception is important to identify using a conception diagnostic test, so that misconception is immediately corrected. Unfortunately, standardized conception diagnostic tests is not yet available. This paper is intended to report the development of a five-tier conception diagnostic test for Straight Motion material, to test its validity and reliability as well as a limited trial to a number of students. 13 valid and reliable questions were obtained so that they were ready to be tested. The internal validity test obtained $94 \%$ (valid). The external validity consists of content and construct empirical aspects. The content aspect was valid because the false positive (FP) and false negative (FN) values are $3.27 \%$ dan $8.22 \%$. The construct empirical aspect was determined based on the Pearson product moment, the reliability by the Alpha Cronbarch with $r_{\text {table }}=0.388$ (5\% significance level), $r_{x y}=0.549$ and $r_{11}=0.747$. The limited trials suggested that most students experienced lack of knowledge.
\end{abstract}

Keywords: Straight motion; five-tier diagnostic test; validity; reliabily; limited test.

\begin{abstract}
ABSTRAK
Mata pelajaran Fisika masih sulit dipahami siswa SMA, termasuk pada materi Gerak Lurus. Sebagai contoh, siswa menganggap bahwa sebuah bolpoin yang dijatuhkan di atas lantai merupakan contoh gerak jatuh bebas. Menurut konsep Fisika, pada peristiwa gerak jatuh bebas, benda yang bergerak hanya dipengaruhi oleh gaya gravitasi dan benda berada dalam keadaan tidak setimbang. Sementara saat bolpoin dijatuhkan, gaya yang berpengaruh tidak hanya gaya gravitasi saja, tetapi juga gaya dari tangan siswa. Ketidaksesuaian antara anggapan siswa dengan konsep Fisika tersebut menunjukkan bahwa siswa mengalami apa yang disebut miskonsepsi. Miskonsepsi ini penting untuk diidentifikasi dengan tes diagnostik konsepsi agar segera dibenahi. Namun sayang, tes diagnostik konsepsi yang terstandar belum tersedia. Makalah ini dimaksudkan untuk melaporkan hasil pengembangan tes diagnostik konsepsi lima tingkat untuk materi Gerak Lurus, menguji validitas dan reliabilitas serta uji coba terbatas kepada sejumlah siswa. 13 butir soal yang valid dan reliabel diperoleh sehingga siap diuji cobakan. Uji validitas internal memperoleh $94 \%$ (valid). Validitas eksternal terdiri dari validitas isi dan konstruk. Validitas isi instrumen dinyatakan valid karena nilai false positive $(\mathrm{FP})$ dan false negative $(\mathrm{FN})=3,27 \%$ dan $8,22 \%$. Validitas empiris konstruk ditentukan berdasarkan Pearson product moment dan reliabilitas dengan Alpha Cronbarch dengan $r_{\text {tabel }}=0,388$ (taraf signifikansi 5\%) diperoleh $r_{x y}=0,549$ dan $r_{11}=0,747$. Hasil uji coba terbatas menyarankan bahwa sebagian besar siswa mengalami lack of knowledge .
\end{abstract}

Kata kunci: Gerak Lurus; tes diagnostik konsepsi lima tingkat, validitas, reliabilitas, uji terbatas. 


\section{PENDAHULUAN}

Fisika merupakan salah satu mata pelajaran IPA yang diajarkan di SMA. Menurut Adi \& Okatviani (2019), untuk memahami suatu konsep, dibutuhkan pemahaman yang baik terlebih dahulu pada konsep lainnya yang menjadi syarat. Sebagai contoh, untuk memahami konsep Perpindahan maka siswa harus memahami terlebih dahulu konsep Vektor. Serway (2004) dalam bukunya yang berjudul "Physics for Scientists and Engineers" mengungkapkan bahwa Jarak merupakan besaran Skalar dan Perpindahan merupakan besaran Vektor. Besaran Vektor tidak hanya memiliki nilai, tetapi juga memiliki arah dari perubahan posisi tersebut. Pada penelitian sebelumnya yang dilakukan oleh Qonita \& Ermawati (2020) yang berjudul "The Validity and Reliability of Five Tier Diagnostic Test for Vector Conception" diketahui bahwa siswa berasumsi ketika suatu benda bergerak pada lintasan tertentu dan kembali ke posisi semula dengan lintasan berbeda, maka perpindahannya tidak sama dengan nol. Sedangkan menurut konsep Vektor yang dikemukakan oleh Tyndal (2013) dalam buku yang berjudul "College Physics in Sciences", Perpindahan benda bernilai nol saat benda bergerak dan kembali ke posisi semula, baik benda tersebut bergerak dengan jalur yang sama maupun berbeda. Jannah \& Ermawati (2019) mengungkapkan bahwa perbedaan yang terjadi antara pemahaman siswa dengan konsep Fisika disebut miskonsepsi. Apabila siswa mengalami miskonsepsi pada konsep tersebut, maka siswa juga akan berpotensi mengalami miskonsepsi pada konsep lainnya, seperti Jarak dan Perpindahan, Kecepatan dan Kelajuan, Gerak Lurus Beraturan (GLB) dan Gerak Lurus Berubah Beraturan (GLBB), serta Gerak Jatuh Bebas (GJB) yang merupakan bagian dari materi Gerak Lurus.

Miskonsepsi pada materi Gerak Lurus tersebut telah Penulis temukan ketika melakukan kegiatan Pengenalan Lapangan Persekolahan (PLP) pada salah satu SMA Negeri di Gresik. ditemukan bahwa siswa menganggap peristiwa menjatuhkan bolpoin merupakan contoh dari peristiwa GJB. Menurut Young \& Freedman (2013) dalam bukunya yang berjudul "University Physics with Modern Physics" bahwa gerak jatuh bebas adalah gerak yang timbul akibat adanya gaya gravitasi dan benda berada dalam keadaan tidak setimbang. Miskonsepsi lainnya juga Penulis temukan pada konsep GLBB. Ketika Penulis bertanya kepada siswa mengenai mobil yang mengalami GLBB dengan penambahan kecepatan, maka siswa menganggap bahwa mobil yang mengalami penambahan kecepatan tersebut akan mengalami penambahan percepatan. Sementara menurut Serway (2004) percepatan benda yang mengalami GLBB adalah konstan.

Berdasarkan beberapa data miskonsepsi di atas, maka diperlukan identifikasi lebih lanjut untuk mengetahui level konsepsi siswa. Beberapa cara yang dapat dilakukan untuk mengetahui level konsepsi siswa adalah dengan tes diagnostik mulai dari tes wawancara, tes terbuka/open-ended test, tes diagnostik pilihan ganda yaitu yaitu tes diagnostik dua tingkat ( $t w o-$ tier), tes diagnostik tiga tingkat (three-tier) atau tes diagnostik empat tingkat (four-tier) (Katalkci, 2015). Tes diagnostik empat tingkat terdiri dari: tingkat pertama berisi beberapa pilihan jawaban, tingkat kedua berisi keyakinan siswa dalam memilih jawaban yang benar, tingkat ketiga berisi beberapa pilihan alasan dalam memilih jawaban yang benar pada tingkat pertama dan tingkat keempat berisi tingkat kepercayaan dalam memilih alasan yang benar pada tingkatan ketiga (Kurniawati \& Ermawati 2019).

Saat ini tes diagnostik empat tingkat telah dikembangkan menjadi lima tingkat (five-tier) yaitu oleh Bayuni dkk (2018) dengan penelitiannya yang berjudul "Identification misconception of primary school teacher education students in changes of matters using a five-tier diagnostic test" dan Anam, dkk (2019) dengan penelitiannya yang berjudul "Developing a five-tier diagnostic test to identify students" misconceptions in science: an example of the heat transfer concepts". Selain itu pada tahun berikutnya telah dikembangkan pula tes diagnostik konsepsi dengan format lima tingkat oleh Qonita \& Ermawati (2020) untuk materi Vektor, Fajriyyah \& Ermawati (2020) untuk materi Teori Kinetik Gas serta, Salsabila \& Ermawati (2020) untuk materi Elastisitas. Tes diagnostik lima tingkat memiliki tambahan tier yaitu jawaban terbuka yang dapat berupa gambar atau pernyataan untuk mengkonfirmasi jawaban. Menurut Qonita \& Ermawati (2020) tambahan 
tingkat kelima tersebut bertujuan untuk memfasilitasi siswa dalam mengekspresikan pengetahuannya dan mengkonfirmasi jawaban pada tingkat satu dan alasan pada tingkat empat. Dengan demikian, hasil identifikasi level konsepsi dengan tes diagnostik lima tingkat ini lebih akurat. Namun sayang, hingga saat ini instrumen tes diagnostik konsepsi yang telah terstandar belum tersedia sehingga apabila dibutuhkan, instrumen tersebut harus ditulis terlebih dahulu. Tabel 1 menunjukkan kategori kombinasi jawaban pada tes diagnostik lima tingkat dan level konsepsinya. Sedangkan Tabel 2 memberikan deskripsi dan skor jawaban pada tier kelima pada Tabel 1 tersebut.

Tabel 1. Kombinasi jawaban five-tier dan level konsepsinya (Amin, 2016; Anam, 2019)

\begin{tabular}{|c|c|c|c|c|c|c|}
\hline \multirow[b]{2}{*}{ No } & \multicolumn{5}{|c|}{ Kombinasi jawaban tier ke- } & \multirow{2}{*}{$\begin{array}{c}\text { Level } \\
\text { kon- } \\
\text { Sepsi }\end{array}$} \\
\hline & 1 & 2 & 3 & 4 & 5 & \\
\hline \multirow{4}{*}{1.} & & & & & SD/SC & $S C$ \\
\hline & & & & & $\begin{array}{l}\mathrm{PD} / \mathrm{PC} \\
\mathrm{MD} / \mathrm{MC}\end{array}$ & $A S C$ \\
\hline & B & Y & B & $Y$ & $\begin{array}{l}\mathrm{MD} / \mathrm{MC} \\
\mathrm{UD} / \mathrm{UC}\end{array}$ & $L K$ \\
\hline & & & & & $\mathrm{ND} / \mathrm{NC}$ & $U n C$ \\
\hline 2. & B & $\bar{Y}$ & B & TY & \multirow{11}{*}{$\begin{array}{c}(\mathrm{PD} / \mathrm{PC}) / \\
(\mathrm{MD} / \mathrm{MC}) / \\
(\mathrm{UD} / \mathrm{UC}) / \\
(\mathrm{ND} / \mathrm{NC})\end{array}$} & \multirow{11}{*}{$(\mathrm{LK})$} \\
\hline 3. & B & TY & B & Y & & \\
\hline 4. & B & TY & $\mathrm{B}$ & TY & & \\
\hline 5. & B & $\mathrm{Y}$ & $\mathrm{S}$ & TY & & \\
\hline 6. & B & TY & $\mathrm{S}$ & Y & & \\
\hline 7. & $S$ & TY & $\mathrm{S}$ & Y & & \\
\hline 8. & $S$ & $\mathrm{Y}$ & $\mathrm{B}$ & TY & & \\
\hline 9. & S & TY & B & $\mathrm{Y}$ & & \\
\hline 10. & S & TY & B & TY & & \\
\hline 11. & $S$ & $\mathrm{Y}$ & B & $\mathrm{Y}$ & & \\
\hline 12. & S & TY & B & TY & & \\
\hline 13. & $S$ & $\mathrm{Y}$ & $\mathrm{S}$ & TY & \multirow{3}{*}{$\begin{array}{c}\mathrm{PD} / \mathrm{PC}) / \\
(\mathrm{MD} / \mathrm{MC}) / \\
(\mathrm{UD} / \mathrm{UC}) / \\
(\mathrm{ND} / \mathrm{NC}) \\
\end{array}$} & \multirow{3}{*}{$(\mathrm{NU})$} \\
\hline 14. & S & $\mathrm{TY}$ & $\mathrm{S}$ & $\mathrm{Y}$ & & \\
\hline 15. & S & TY & $\mathrm{S}$ & TY & & \\
\hline 16. & $S$ & Y & $\mathrm{S}$ & Y & $\begin{array}{l}\text { (MD/MC)/ } \\
(\mathrm{UD} / \mathrm{UC}) / \\
(\mathrm{ND} / \mathrm{NC})\end{array}$ & (MSC) \\
\hline 17. & & $\begin{array}{r}\text { rda } \\
\text { at: }\end{array}$ & & $\mathrm{y}$ & $\begin{array}{l}\text { dak terjawab } \\
\text { sari satu }\end{array}$ & (UnC) \\
\hline
\end{tabular}

Keterangan:

$\mathrm{B}=$ Benar, $\mathrm{S}=$ Salah, $\mathrm{Y}=$ Yakin, $\mathrm{TY}=$ Tidak Yakin, $\mathrm{SD} / \mathrm{SC}=$ Scientific Drawing/Scientific Conclusion, $\mathrm{PD} / \mathrm{PC}=$ Partial Drawing/Partial Conclusion, $\mathrm{MD} / \mathrm{MC}=$ Misconception Drawing/Misconception
Conclusion, UD/UC= Undefined Drawing/Undefined Conclusion, $\mathrm{ND} / \mathrm{NC}=$ No Drawing/No Conclusion . $\mathrm{SC}=$ Scientific Conception, ASC $=$ Almost Scientific Conception, $\mathrm{LK}=$ Lack of Knowledge, $\mathrm{NU}=\mathrm{No}$ Understanding on Conception, $\mathrm{MSC}=$ Misconception, $\mathrm{UnC}=$ Un Code.

Tabel 2. Deskripsi dan skor jawaban pada tier kelima pada Tabel 1 (Dikmenli, 2010; Köse, S., 2008)

\begin{tabular}{|c|c|c|c|}
\hline No & Kategori & Deskripsi & $\begin{array}{c}\text { Skor } \\
(\%)\end{array}$ \\
\hline 1 & $S D / S C$ & $\begin{array}{l}\text { Siswa memberikan } \\
\text { jawaban yang benar } \\
\text { dengan } \\
\text { gambar/kesimpulan yang } \\
\text { sesuai dengan konsep } \\
\text { Fisika. }\end{array}$ & 100 \\
\hline 2 & $P D / P C$ & $\begin{array}{l}\text { Siswa memberikan } \\
\text { gambar/kesimpulan } \\
\text { sebagian sesuai dengan } \\
\text { konsep Fisika. }\end{array}$ & $99-70$ \\
\hline 3 & $M D / M C$ & $\begin{array}{l}\text { Siswa memberikan } \\
\text { jawaban yang salah dan } \\
\text { gambar/kesimpulan } \\
\text { berbeda dengan konsep } \\
\text { Fisika. }\end{array}$ & $69-40$ \\
\hline 4 & $U D / U C$ & $\begin{array}{l}\text { Siswa memberikan } \\
\text { jawaban yang tidak dapat } \\
\text { dipahami atau } \\
\text { gambar/kesimpulannya } \\
\text { tidak sesuai dengan } \\
\text { konsep Fisika. }\end{array}$ & $39-1$ \\
\hline 5 & $N D / N C$ & $\begin{array}{l}\text { Siswa tidak memberikan } \\
\text { jawaban. }\end{array}$ & 0 \\
\hline
\end{tabular}

Keterangan:

$\mathrm{SD} / \mathrm{SC}=$ Scientific Drawing/Scientific Conclusion, $\mathrm{PD} / \mathrm{PC}=$ Partial Drawing/Partial Conclusion, $\mathrm{MD} / \mathrm{MC}=$ Misconception Drawing/ Misconception Conclusion, UD/UC= Undefined Drawing/Undefined Conclusion, ND/NC= No Drawing/No Conclusion.

Berdasarkan uraian di atas, makalah ini melaporkan hasil pengembangan tes diagnostik konsepsi lima tingkat untuk materi Gerak Lurus, uji validitas dan reliabilitas, serta uji coba terbatas kepada sejumlah siswa untuk mendapatkan gambaran tentang level konsepsi para siswa uji untuk materi Gerak Lurus. 


\section{METODE PENELITIAN}

Penelitian ini menggunakan metode research and development (R\&D). Tahap research dilakukan dengan mengkaji literatur untuk materi Gerak Lurus (khususnya pada lima sub-konsep, yaitu: Jarak dan Perpindahan, Laju rata-rata dan Kecepatan rata-rata, GLB dan GLBB, Karakteristik GJB serta Kecepatan pada GJB) pada buku Serway (2004) yang berjudul "Physics for Scientists and Engineers", Halliday \& Resnick (2011) yang berjudul "Fundamental of Physics", dan Young \& Freedman (2013) yang berjudul "University Physics and Modern Physics". Kemudian Penulis mengkaji dan merekap potensi miskonsepsi siswa, baik melalui studi literatur di atas maupun melalui pengamatan langsung pada saat Penulis mengikuti kegiatan PLP di salah satu SMAN di Gresik. Tabel 3 menampilkan 3 dari 5 subkonsep beserta potensi miskonsepsi untuk materi Gerak Lurus yang telah dikaji oleh Penulis tersebut.

Tabel 3. Rekapitulasi ke-3 dari 5 sub-konsep dalam materi Gerak Lurus beserta potensi miskonsepsi

\begin{tabular}{|c|c|c|}
\hline $\begin{array}{c}\text { Sub } \\
\text { Konsep }\end{array}$ & $\begin{array}{c}\text { Potensi } \\
\text { Miskonsepsi }\end{array}$ & Konsep yang Benar \\
\hline $\begin{array}{l}\text { Jarak } \\
\text { dan } \\
\text { Perpin- } \\
\text { Dahan }\end{array}$ & $\begin{array}{l}\text { Siswa } \\
\text { menganggap } \\
\text { bahwa jarak } \\
\text { dan } \\
\text { perpindahan } \\
\text { adalah sama. }\end{array}$ & $\begin{array}{l}\text { Jarak adalah panjang } \\
\text { lintasan yang ditempuh } \\
\text { oleh benda terhadap } \\
\text { titik acuan. Perpindahan } \\
\text { merupakan perubahan } \\
\text { posisi dari posisi awal } \\
\text { ke posisi akhir. Jarak } \\
\text { merupakan besaran } \\
\text { skalar dan perpindahan } \\
\text { merupakan besaran } \\
\text { Vektor. }\end{array}$ \\
\hline $\begin{array}{l}\text { Karakter } \\
\text { istik } \\
\text { Gerak } \\
\text { Jatuh } \\
\text { bebas }\end{array}$ & $\begin{array}{l}\text { Siswa } \\
\text { menganggap } \\
\text { bahwa semua } \\
\text { benda yang } \\
\text { bergerak vertikal } \\
\text { ke bawah } \\
\text { merupakan } \\
\text { gerak jatuh }\end{array}$ & $\begin{array}{l}\text { Gerak jatuh bebas } \\
\text { adalah gerak yang } \\
\text { timbul akibat adanya } \\
\text { gaya gravitasi dan } \\
\text { benda tidak berada } \\
\text { dalam kesetimbangan. }\end{array}$ \\
\hline
\end{tabular}

\section{bebas.}

Siswa

Kecepa- menganggap Kecepatan benda ketika tan pada massa dan mengalami gerak jatuh Gerak bentuk benda bebas dipengaruhi oleh Jatuh mempengaruhi gaya gravitasi dan Bebas kecepatan gerak ketinggian benda. jatuh bebas.

Tahap development dilakukan dengan menyusun Draf ke-1 (14 butir soal) berupa tes diagnostik three-tier. Kemudian Penulis melakukan uji coba awal Draf ke-1 tersebut kepada 33 siswa SMA di Surabaya, Sidoardjo, Bangkalan dan Denpasar yang sebelumnya telah memperoleh materi Gerak Lurus di sekolahnya masing-masing dengan tujuan menjaring alasan oleh siswa uji untuk menjawab pertanyaan pada tier 1 Hasil dari uji coba awal tersebut selanjutnya dituangkan dalam Draf ke-2.

Draf ke-2 (14 butir soal) berupa instrumen five-tier untuk diuji validitas internalnya oleh dua Dosen Fisika UNESA yang ditunjuk. Validitas internal tersebut terdiri dari aspek validitas isi, bahasa dan konstruk. Indikator untuk menilai validitas isi meliputi: (a) butir-butir soal sesuai dengan materi Gerak Lurus. (b) Butir-butir soal sesuai dengan indikator soal. (c) Uraian butir soal sesuai dengan urutan materi. (d) Batasan pertanyaan, jawaban dan penjelasan alasan yang diharapkan haruslah jelas.

Sedangkan indikator validitas konstruk meliputi: (a) petunjuk tes diagnostik harus dinyatakan dengan jelas. (b) Kesesuaian antara kriteria butir soal dengan taksonomi Bloom dan kompetensi dasar. (c) Setiap butir tes diagnostik dapat mengidentifikasi konsepsi peserta didik. (d) Pilihan alasan yang disajikan dapat mengungkapkan penyebab miskonsepsi yang bersumber dari dalam diri peserta didik. (e) Pengecoh pada pilihan alasan harus besifat rasional dan homogen dengan jawaban tier pertama. (f) Tabel, grafik, gambar dan sejenisnya harus bersesuaian dengan masalah yang disajikan. Indikator validitas bahasa meliputi: (a) 
kalimat soal harus menggunakan Bahasa Indonesia yang baik dan benar. (b) Ragam kalimat atau pertanyaan tidak boleh menimbulkan penafsiran ganda. (c) Pertanyaan setiap butir tes dinyatakan dengan jelas dan komunikatif. Penilaian validitas internal dilakukan sesuai dengan rubrik penilaian dengan memberikan skor 1-4 seperti pada Tabel 4. Adapun persentase $(\%)$ validitas internal dihitung menggunakan Pers. (1) dengan kriteria interpretasinya pada Tabel 5.

Tabel 4. Rubrik penilaian validitas internal beserta kriteria nilainya (Sugiyono, 2015)

\begin{tabular}{c|c}
\hline Rubrik Penilaian & Kriteria Interpretasi Nilai \\
\hline 1 & $0-39 \%$ terpenuhi \\
2 & $40-69 \%$ terpenuhi \\
3 & $70-89 \%$ terpenuhi \\
4 & $90-100 \%$ terpenuhi \\
\hline
\end{tabular}

$$
P=\frac{s_{R}}{N \cdot P_{A} \cdot R} \times 100 \%
$$

dimana $P=$ persentase validitas internal, $S_{R}=$ jumlah skor dari validator, $N=$ skor maksimum pada aspek validitas dan $R=$ jumlah validator.

Tabel 5. \% Validitas internal dan kriteria interpretasinya (Riduwan dan Akdon, 2013:18)

\begin{tabular}{c|c}
\hline Presentse (\%) & Kriteria Interpretasi \\
\hline $0-20$ & Sangat tidak valid \\
$21-40$ & Kurang valid \\
$41-60$ & Cukup valid \\
$61-80$ & Valid \\
$81-100$ & Sangat valid \\
\hline
\end{tabular}

Hasil uji validitas internal tersebut dituangkan dalam Draf ke-3. Draft ke-3 tersebut selanjutnya diuji validitas eksternal dan reliabilitas kepada 24 siswa SMA lainnya yang juga berasal dari beberapa daerah di Jawa Timur. Uji validitas eksternal terdiri dari validitas empiris isi dan validitas empiris konstruk, dimana validitas empiris isi dilakukan dengan menghitung \% jawaban false positives (FP) dan false negatives (FN) dengan Pers (2) dan (3) (Kribulut \& Geban, 2014). Jawaban FP tersebut adalah apabila siswa menjawab benar pertanyaan tier ke-1 dan yakin dengan jawaban tersebut, namun alasan salah (yaitu opsi No. 5 pada Tabel 1). Sedangkan jawaban $F N$ adalah apabila siswa menjawab salah pertanyaan tier ke-1 dan yakin dengan jawaban salah tersebut, namun alasannya benar (yaitu opsi No. 11 pada Tabel 1). Validitas isi dikatakan terpenuhi apabila baik nilai $F P$ dan FN masing-masing $<10 \%$.

$$
\begin{aligned}
& \% F P=\frac{\sum F P}{\sum_{\text {items }} \times \sum_{P D}} \times 100 \% \\
& \% F N=\frac{\sum F N}{\sum_{\text {items }} \times \sum_{P D}} \times 100 \%
\end{aligned}
$$

dimana $\Sigma F P=$ jumlah $F P, \quad \Sigma F N=$ jumlah $F N$, $\Sigma$ items $=$ jumlah soal, dan $\Sigma P D=$ jumlah siswa uji.

Validitas empiris konstruk dihitung dengan Pers. (4) korelasi Pearson Product Moment (Arikunto, 2013) dengan kriteria pada Tabel 6. Reliabilitas dihitung menggunakan Pers. (5) koefisien Alfa Cronbach ( $\mathrm{r}_{11}$ ) (Sugiyono, 2015) dengan kriteria pada Tabel 7.

$$
r_{x y}=\frac{\sum x y}{\sqrt{\left(\sum x^{2}\right)\left(\sum y^{2}\right)}}
$$

Dimana $r_{x y}=$ korelasi antara variabel $x$ dan $y, x=$ selisih antara jumlah skor jawaban benar tiap butir soal pada tier pertama dan ketiga dengan rata-rata skor jawaban benar pada semua butir soal dan $y=$ selisih antara jumlah skor jawaban yakin tiap butir soal pada tier kedua dan keempat dengan rata-rata skor jawaban benar pada semua butir soal.

Tabel 6. Interpretasi koefisien korelasi Product Moment (Sugiyono, 2015)

\begin{tabular}{c|c}
\hline Angka Korelasi $\left(\mathbf{r}_{\mathbf{x y}}\right)$ & Kriteria \\
\hline $0,800-1,000$ & Sangat tinggi \\
$0,600-0,799$ & Tinggi \\
$0,400-0,599$ & Sedang \\
$0,200-0,399$ & Rendah \\
$0,000-0,199$ & Sangat rendah \\
\hline \\
$r_{11}=\frac{k}{k-1}\left(1-\frac{\sum \sigma_{b}^{2}}{\sigma_{t}^{2}}\right)$
\end{tabular}

dimana $r_{11}=$ koefisien reliabilitas instrumen yang dikembangkan, $k=$ jumlah soal, $\sigma_{b}^{2}=$ varian skor tiap butir soal, $\sigma_{t}^{2}=$ varian total. 
Tabel 7. Kriteria reliabilitas Alfa Cronbach

\begin{tabular}{c|c}
\hline Angka Korelasi $\left(\mathbf{r}_{\mathbf{x y}}\right)$ & Kriteria \\
\hline $0,800-1,000$ & Sangat tinggi \\
$0,600-0,799$ & Tinggi \\
$0,400-0,599$ & Sedang \\
$0,200-0,399$ & Rendah \\
$0,000-0,199$ & Sangat rendah \\
\hline
\end{tabular}

Hasil uji validitas eksternal dan reliabilitas tersebut membuahkan Draf akhir tes diagnostik five-tier (13 butir soal). Salah satu butir soal tersebut diberikan pada Tabel 8. Draf akhir dipergunakan untuk uji coba terbatas kepada 8 orang siswa lain yang belum pernah terlibat di dalam kegiatan penelitian ini. Tujuan dari kegiatan uji coba tersebut adalah untuk menguji level konsepsi para siswa tersebut pada materi Gerak Lurus.

\section{HASIL DAN PEMBAHASAN}

\section{A. Pengembangan Instrumen}

Seperti dijelaskan, Tabel 8 berisi salah satu dari ke-13 butir soal yang ada di dalam Draft akhir. Kedua belas soal lainnya tidak Penulis sertakan karena pada waktu yang bersamaan dokumen tersebut sedang diajukan hak cipta ke Direktorat Jenderal Kekayaan Intelektual, Kemenkumham RI.

Tabel 8. Salah satu dari 13 soal pada Draft akhir

\begin{tabular}{c|ccc}
\hline Tingkat & Pertanyaan \\
\hline \multirow{5}{*}{$\mathbf{1}$} & 1. & Perhatikan Gambar 1. berikut ini. \\
& Gambar 1. Gerak keempat partikel pada \\
lintasan. Sumber : Dokumen pribadi. \\
$\begin{array}{l}\text { Pada keempat lintasan tersebut, terlihat } \\
\text { bahwa objek bergerak dari titik awal ke } \\
\text { titik akhir dalam interval waktu yang } \\
\text { sama. Jarak antar lintasan garis lurus } \\
\text { bernilai sama besar. Tentukan urutan } \\
\text { objek berdasarkan urutan laju rata- } \\
\text { rata yang akan dialami objek dari yang }\end{array}$
\end{tabular}

\begin{tabular}{c|l}
\hline & terbesar hingga kecepatan rata-rata \\
& terkecil.... \\
& a. $\quad \mathbf{4}, \mathbf{1}, \mathbf{2}, \mathbf{3}$ \\
& b. $\quad 4,3,2,1$ \\
& c. $\quad 1,2,4,3$ \\
& d. $\quad$ Sama \\
\hline Tingkat & \multicolumn{2}{|c}{ Tingkat keyakinan Jawaban } \\
$\mathbf{2}$ & a. $\quad$ Yakin \\
& b. Tidak yakin \\
\hline
\end{tabular}

\begin{tabular}{|c|c|}
\hline Tingkat & Alasan \\
\hline 3 & $\begin{array}{l}\text { A. Karena selisih perubahan posisi } \\
\text { partikel 1, 2, 3, } 4 \text { sama maka nilai laju } \\
\text { rata-ratanya juga sama. (pemikiran } \\
\text { humanistik) }\end{array}$ \\
\hline
\end{tabular}

B. Karena total lintasan yang ditempuh paling banyak adalah partikel 4 dan disusul dengan partikel 1 dan 2 yang memiliki panjang lintasan yang sama besar, dan yang terkecil panjang lintasan dari partikel 3 .

C. Laju rata rata merupakan perubahan posisi (perpindahan) yang ditempuh oleh suatu benda tiap satuan waktu. (intuisi yang salah)

D. Laju rata rata merupakan besaran vector karena itu arah dari posisi menentukan kelajuan benda tersebut.(pra konsepsi)

E. Karena nilai perpindahan terbesar ada pada partikel 4 dan partikel 1 dan 2 bernilai sama juga perpindahan terkecil berada pada partikel ke 3.(Pemikiran Asosiatif)

F. Laju rata-rata merupakan besar selisih jarak yang ditempuh tiap satuan waktu.(Reasoning yang salah)

\begin{tabular}{|c|c|}
\hline $\begin{array}{c}\text { Tingkat } \\
\mathbf{4}\end{array}$ & $\begin{array}{l}\text { Tingkat keyakinan Jawaban } \\
\text { a. Yakin } \\
\text { b. Tidak yakin }\end{array}$ \\
\hline $\begin{array}{c}\text { Tingkat } \\
5\end{array}$ & $\begin{array}{l}\text { Coba lengkapi nilai panjang lintasan } \\
\text { yang ditempuh partikel } 1,2,3, \text { dan } 4 \\
\text { tersebut! } \\
\begin{array}{l}\Delta x_{1}=a+a+a=3 a \\
\Delta x_{2}=a+a+a=3 a \\
\Delta x_{3}=a=a \\
\Delta x_{4}=a+\frac{1}{2 a}+\frac{1}{2 a}+a+\frac{1}{2 a}+\frac{1}{2 a}+a=\end{array}\end{array}$ \\
\hline
\end{tabular}

Kemudian, lengkapi rumus dari laju rata rata berikut!

$$
\text { kecepatan }=\frac{\text { jarak }}{\text { waktu }}
$$

Pada Tabel 8 tersebut tier/tingkat-1 berisi soal pilihan ganda dengan 4 pilihan jawaban yang terdiri dari 1 jawaban benar dan 3 jawaban 
pengecoh. Tingkat 2 berisi tingkat keyakinan jawaban pada Tingkat 1 . Tingkat 3 berisi 6 pilihan alasan jawaban pada Tingkat 1 yang terdiri dari 1 alasan jawaban benar dan 5 alasan jawaban pengecoh. Ragam pilihan alasan jawaban pengecoh pada Tingkat 3 tersebut dibuat berdasarkan penyebab miskonsepsi yang berasal dari diri siswa, yaitu prakonsepsi, pemikiran humanistik, reasoning yang salah, pemikiran asosiatif dan intuisi yang salah. Tingkat 4 berisi tingkat keyakinan alasan jawaban dari tingkat 3 . Tingkat 5 berupa pertanyaan terbuka untuk mengkonfirmasi jawaban dan alasan siswa pada Tingkat 1 dan 3, sekaligus untuk menghindari jawaban siswa yang berupa tebakan (Salsabila \& Ermawati, 2020).

\section{Hasil Validasi dan Reliabilitas}

Tabel 9-11 berturut-turut menyajikan hasil rekapitulasi validitas internal, validitas eksternal empiris isi dan validitas eksternal empiris konstruk dari Draft ke-2. Sedangkan Gambar 2 menunjukkan nilai $r_{\text {tabel }}$ yang digunakan dalam penelitian ini. Nilai $r_{\text {tabel }}$ yang digunakan tersebut adalah yang diberi kotak merah dengan $r_{\text {tabel }}$ Nomor 24 sesuai dengan jumlah siswa responden dengan signifikani $5 \%$.

Tabel 9. Rekapitulasi hasil validitas internal

\begin{tabular}{|c|c|c|c|c|c|c|}
\hline \multirow[t]{2}{*}{ No } & \multirow[t]{2}{*}{ Aspek } & \multirow[t]{2}{*}{ Indikator } & \multicolumn{2}{|c|}{ Validator } & \multirow{2}{*}{$\begin{array}{c}\text { Persentase } \\
(\%)\end{array}$} & \multirow[t]{2}{*}{ Kriteria } \\
\hline & & & 1 & 2 & & \\
\hline \multirow{4}{*}{1.} & \multirow{4}{*}{ Isi } & (a) & 4 & 4 & \multirow{4}{*}{100} & \multirow{4}{*}{$\begin{array}{l}\text { Sangat } \\
\text { Valid }\end{array}$} \\
\hline & & (b) & 4 & 4 & & \\
\hline & & (c) & 4 & 4 & & \\
\hline & & (d) & 4 & 4 & & \\
\hline \multirow{6}{*}{2.} & \multirow{6}{*}{ Konstruk } & (a) & 4 & 4 & \multirow{6}{*}{97} & \multirow{6}{*}{$\begin{array}{c}\text { Sangat } \\
\text { Valid }\end{array}$} \\
\hline & & (b) & 3 & 4 & & \\
\hline & & (c) & 4 & 4 & & \\
\hline & & (d) & 3 & 4 & & \\
\hline & & (e) & 4 & 4 & & \\
\hline & & (f) & 4 & 3 & & \\
\hline \multirow{3}{*}{3.} & \multirow{3}{*}{ Bahasa } & (a) & 4 & 3 & \multirow{3}{*}{88} & \multirow{3}{*}{$\begin{array}{c}\text { Sangat } \\
\text { Valid }\end{array}$} \\
\hline & & (b) & 4 & 3 & & \\
\hline & & (c) & 4 & 3 & & \\
\hline \multicolumn{5}{|c|}{ Rata-rata } & 94 & $\begin{array}{c}\text { Sangat } \\
\text { Valid }\end{array}$ \\
\hline
\end{tabular}

Keterangan: Indikator 1(a)-1(d), 2(a)-2(f), dan 3(a)3(c) dapat dilihat pada teks di bawah Metode
Penelitia, sedangkan kriteria validitas internal tersebut pada Tabel 5.

Tabel 10. Hasil validitas eksternal empiris isi

\begin{tabular}{cccc}
\hline No. Soal & $\boldsymbol{\Sigma}$ Siswa & $\boldsymbol{\Sigma} \boldsymbol{F P}$ & $\boldsymbol{\Sigma} \boldsymbol{F} \boldsymbol{N}$ \\
\hline $\mathbf{1}$ & & 2 & 2 \\
$\mathbf{2}$ & & 7 & 0 \\
$\mathbf{3}$ & & 4 & 2 \\
$\mathbf{4}$ & & 0 & 2 \\
$\mathbf{5}$ & & 0 & 0 \\
$\mathbf{6}$ & & 0 & 7 \\
$\mathbf{7}$ & \multirow{2}{*}{24} & 0 & 0 \\
$\mathbf{8}$ & & 1 & 0 \\
$\mathbf{9}$ & & 0 & 0 \\
$\mathbf{1 0}$ & & 0 & 8 \\
$\mathbf{1 1}$ & & 1 & 5 \\
$\mathbf{1 2}$ & & 0 & 2 \\
$\mathbf{1 3}$ & & 1 & 0 \\
$\mathbf{1 4}$ & & 0 & 0 \\
\hline Persentase & 3,27 & 8,33 \\
\hline
\end{tabular}

Tabel 11. Hasil validitas eksternal konstruk

\begin{tabular}{c|ccc}
\hline $\begin{array}{c}\text { Nomor } \\
\text { Soal }\end{array}$ & $\mathrm{r}_{\mathrm{xy}}$ & $\mathrm{r}_{\text {tabel }}$ & Kriteria \\
\hline 1 & 0.502262 & & Valid \\
2 & -0.1183 & & Tidak \\
& & valid \\
3 & 0.68814 & & Valid \\
4 & 0.486265 & & Valid \\
5 & 0.631917 & & Valid \\
6 & 0.781397 & & Valid \\
7 & 0.943646 & 0,388 & Valid \\
8 & 0.838398 & & Valid \\
9 & 0.876346 & & Valid \\
10 & 0.909211 & & Valid \\
11 & 0.937135 & & Valid \\
12 & 0.911819 & & Valid \\
13 & 0.935766 & & Valid \\
14 & 0.991274 & & Valid \\
\hline
\end{tabular}

Data pada Tabel 9 tersebut menunjukkan bahwa secara aspek validitas isi, bahasa dan konstruk Draf ke-3 yang telah dikembangkan tersebut memiliki kriteria sangat valid dengan nilai validitas internal $94 \%$. Nilai $\% F P$ dan $\% F N$ pada Tabel 10 masing-masing sebesar 3,27\% dan 
$8,33 \%,(<10 \%)$. Oleh karena itu instrumen Draf ke-3 tersebut dinyatakan valid dari segi empiris isi. Tabel 11 menunjukkan bahwa pada validitas konstruk terdapat satu soal (No. 2) yang tidak valid. Oleh karena itu penulis tidak menggunakan soal tersebut pada Draft akhir. Hal ini mengingat sub-konsep Jarak dan Perpindahan yang terkandung di dalam butir soal No. 2 tersebut telah termuat pada No. Soal yang lain, yaitu No. Soal 3-5 dengan model berbeda. Sementara 13 butir soal yang lain, yaitu Soal No. 1, 3 sampai 14 semuanya telah memenuhi kriteria validitas eksternal konstruk karena nilai $r_{x y}>r_{\text {tabel }}$. Nilai reliabilitas $\left(r_{11}\right)$ dari Draf ke-3 tersebut berdasarkan uji validitas dan reliabilitas adalah sebesar 0,747, artinya $r_{11}>r_{\text {tabel }}$ dan instrumen dinyatakan reliabel. Berdasarkan serangkaian uji validitas dan reliabilitas tersebut diperoleh 13 butir soal yang siap untuk diuji cobakan.

\begin{tabular}{|c|c|c|}
\hline \multirow{4}{*}{$\begin{array}{c}d f \\
\text { (degrees of freedom) } \\
\text { atau: } \\
d b . \\
\text { (derajat bebas) }\end{array}$} & \multirow{2}{*}{\multicolumn{2}{|c|}{$\frac{\text { Banyak variabel yang dikorelasikan: }}{2}$}} \\
\hline & & \\
\hline & \multicolumn{2}{|c|}{ Harga " $r$ " pada tąrí signifikansi: } \\
\hline & $5 \%$ & $1 \%$ \\
\hline \multirow{4}{*}{$\begin{array}{l}21 \\
22 \\
23 \\
24\end{array}$} & 0,413 & 0,526 \\
\hline & 0,404 & 0,515 \\
\hline & 0.396 & 0,505 \\
\hline & 0,388 & 0,496 \\
\hline
\end{tabular}

Gambar 2. Tangkapan layar berisi distribusi nilai $\mathrm{r}_{\text {tabel }}$ dengan signifikasi $5 \%$ dan $1 \%$. Sumber: Sudijono (2014).

\section{Hasil Uji Coba Terbatas}

Tabel 12 menunjukkan hasil uji coba terbatas yang dilakukan Penulis kepada 8 siswa SMA yang berasal dari daerah Sidoardjo dan Bangkalan.

Tabel 12. Rekapitulasi hasil uji terbatas terhadap delapan siswa uji

\begin{tabular}{|c|c|c|c|c|c|c|c|c|c|}
\hline \multirow{2}{*}{ NS } & \multicolumn{9}{|c|}{ Level Konsepsi Siswa Ke- } \\
\hline & & 1 & 2 & 3 & 4 & 5 & 6 & 7 & 8 \\
\hline 1. & A & ASC & SC & $\begin{array}{l}\text { MSC } \\
\text { (ph) }\end{array}$ & SC & SC & $\begin{array}{l}\text { MSC } \\
\text { (ph) }\end{array}$ & SC & $\begin{array}{c}\text { MSC } \\
\text { (r) }\end{array}$ \\
\hline 3. & & SC & ASC & LK & LK & SC & SC & SC & SC \\
\hline 4. & $B$ & LK & LK & LK & ASC & SC & LK & SC & LK \\
\hline
\end{tabular}

\begin{tabular}{|c|c|c|c|c|c|c|c|c|}
\hline 5. & LK & LK & NU & $\begin{array}{l}\text { MSC } \\
\text { (ph) }\end{array}$ & LK & $\begin{array}{l}\text { MSC } \\
\text { (pa) }\end{array}$ & LK & LK \\
\hline 6. & SC & $\mathrm{NU}$ & NU & LK & SC & LK & SC & LK \\
\hline 7. & LK & $\mathrm{NU}$ & $\mathrm{NU}$ & LK & SC & LK & SC & LK \\
\hline & $\mathrm{NU}$ & LK & NU & $\begin{array}{c}\text { MSC } \\
\text { (pr) }\end{array}$ & SC & SC & SC & LK \\
\hline 9. & LK & NU & LK & LK & SC & SC & LK & $\mathrm{NU}$ \\
\hline 10. & NU & $\begin{array}{l}\text { VSC } \\
\text { (ph) }\end{array}$ & $\mathrm{NU}$ & LK & LK & LK & LK & LK \\
\hline 11. D & LK & $\begin{array}{l}\text { VSC } \\
\text { (ph) }\end{array}$ & LK & LK & NU & LK & LK & LK \\
\hline 12. & $\begin{array}{c}\text { MSC } \\
\text { PR }\end{array}$ & LK & LK & LK & LK & LK & SC & LK \\
\hline 13. $E$ & LK & $\mathrm{NU}$ & LK & LK & $\begin{array}{l}\text { MSC } \\
\text { (ph) }\end{array}$ & LK & LK & LK \\
\hline 14. & ASC & $\mathrm{NU}$ & $\begin{array}{l}\text { MSC } \\
\text { (ph) }\end{array}$ & $\begin{array}{l}\text { MSC } \\
\text { (ph) }\end{array}$ & $\begin{array}{l}\text { MSC } \\
\text { (ph) }\end{array}$ & LK & $\begin{array}{l}\text { MSC } \\
\text { (ph) }\end{array}$ & $\begin{array}{l}\text { MSC } \\
\text { (ph) }\end{array}$ \\
\hline
\end{tabular}

Keterangan:

$\mathrm{NS}=$ Nomor soal, $\mathrm{SK}=$ Sub konsep, $\mathrm{a}=$ Jarak dan Perpindahan, $b=$ Kecepatan rata-rata dan Laju rata-rata, $c=$ GLB dan GLBB, d= Karakteristik GJB, e= Kecepatan GJB. $\mathrm{SC}=$ Scientific Conception, $\mathrm{ASC}=$ Almost Scientific Conception, $\mathrm{LK}=$ Lack of Knowledge, $\mathrm{NU}=\mathrm{No}$ Understanding on Conception, $\mathrm{MSC}=$ Misconception, $\mathrm{UnC}$ $=$ UnCode. $\mathrm{pr}=$ prakonsepsi, $\mathrm{ph}=$ pemikiran humanistik, $\mathrm{pa}=$ pemikiran asosiatif, $\mathrm{r}=$ reasoning yang salah.

Hasil uji terbatas pada Tabel 12 menunjukkan bahawa level konsepsi paling dominan yang dialami oleh siswa uji pada materi Gerak Lurus adalah lack of knowledge $(47,12 \%)$. Sementara untuk level konsepsi scientific conception, almost scientific conception, misconception, dan no understanding on conception masing-masing sebesar $21,15 \%$; $3,85 \% ; 14,42 \%$ dan $13,46 \%$.

Pada sub konsep Jarak dan Perpindahan, level konsepsi siswa didominasi oleh scientific conception, yang artinya bahwa sebagian besar siswa telah memahami konsep tersebut, namun beberapa siswa lainnya masih belum paham konsep. Pada sub konsep Kecepatan rata-rata dan Laju rata-rata, GLB dan GLBB, Karakteristik GJB serta Kecepatan pada GJB, level konsepsi siswa yang paling dominan adalah lack of knowledge. Sebagai contoh, ketika Penulis memberikan contoh pergerakan dari keempat partikel seperti pada Gambar 1 agar siswa dapat menentukan urutan laju partikel pada soal No. 4 dan urutan kecepatan partikel pada soal No. 5 dari yang terbesar hingga terkecil Lima dari delapan orang siswa mengalami lack of knowledge. Dapat dilihat pada Gambar 4 dan 5 bahwa siswa uji ke-5 dan 7 mengalami 
mengalami scientific conception pada No. Soal 4 dan lack of knowledge pada No. Soal 5. Jawaban kedua siswa pada tier kelima tersebut mengungkapkan bahwa panjang lintasan yang ditempuh partikel pada No. Soal 4 dan 5 memiliki nilai yang sama. Hal ini berarti kedua siswa tersebut tidak benar-benar paham pada No. Soal 4 dan menganggap bahwa konsep kecepatan dan kelajuan adalah sama karena keduanya sama-sama dipengaruhi oleh panjang lintasan yang sama. Menurut konsep Fisika, laju rata-rata merupakan besarnya jarak yang ditempuh benda tiap satuan waktu. Sementara kecepatan rata-rata merupakan besarnya perpindahan yang ditempuh benda tiap satuan waktu (Young \& Freedman, 2013). Oleh karena itu seharusnya nilai panjang lintasan pada soal No. 4 merupakan nilai jarak; dan nilai panjang lintasan pada No. 5 merupakan nilai perpindahan dari tiap partikel.

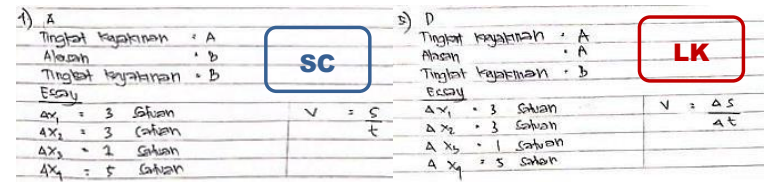

Gambar 3. Jawaban No. Soal 4 dan 5 oleh siswa uji ke-5 yang mengalami scientific conception (SC) dan lack of knowladge (LK).

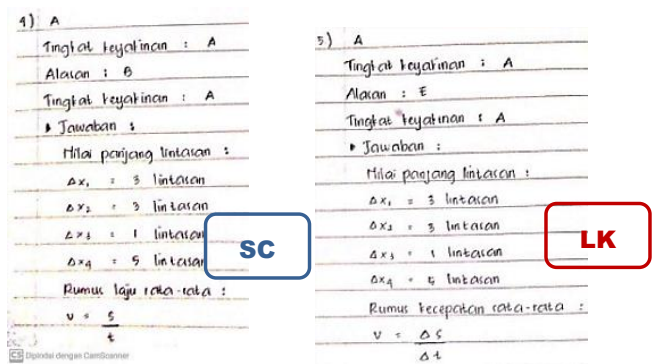

Gambar 4. Jawaban No. Soal 4 dan 5 oleh siswa uji ke-7 yang mengalami scientific conception (SC) dan lack of knowladge (LK).

Miskonsepsi yang terbanyak ditemukan yaitu pada materi Kecepatan GJB. Diketahui 5 dari 8 siswa uji terdeteksi mengalami miskonsepsi yang disebabkan oleh pemikiran humanistik. Pada konsep ini, siswa menganggap apabila dua kertas memiliki massa yang sama dengan bentuk yang berbeda (kertas A berbentuk lembaran dan kertas B diremas) jatuh dari ketinggian yang sama dan koefisien gesek udara diabaikan, maka kertas B akan jatuh terlebih dahulu dibandingkan kertas A. Hal ini menunjukkan bahwa bentuk benda mempengaruhi kecepatan benda yang bergerak jatuh bebas. Sementara menurut konsep Fisika, kecepatan benda yang bergerak jatuh bebas dipengaruhi oleh percepatan gravitasi dan ketinggian benda (Serway, 2004). Gambar 5 menunjukkan bukti jawaban salah satu siswa yang terdeteksi mengalami miskonsepsi pada sub konsep Kecepatan GJB tersebut.

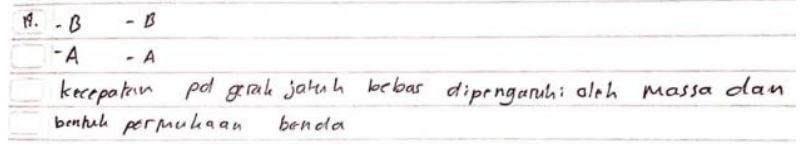

Gambar 5. Jawaban salah seorang siswa uji yang terdeteksi mengalami miskonsepsi pada sub konsep Kecepatan GJB.

Penelitian yang relevan juga dilakukan oleh Pujianto, dkk (2013) yaitu "Analisis Level Konsepsi Siswa pada Konsep Kinematika Gerak Lurus" dengan menggunakan tes pilihan ganda yang disertai Certainity Response Indeks (CRI) dan wawancara pada siswa kelas X SMAN 6 Palu. Penelitian tersebut menunjukkan bahwa $21,67 \%$ siswa paham konsep, $10,42 \%$ siswa hanya menebak jawaban, $17,50 \%$ siswa kurang pengetahuan dan $50 \%$ siswa mengalami miskonsepsi. Selain itu penelitian yang relevan juga dilakukan oleh Yolanda (2017) yang berfokus pada remediasi miskonsepsi kinematika Gerak Lurus dengan pendekatan STAD pada siswa MAN 1 Model Lubuklinggau. Diketahui pada penelitian tersebut bahwa siswa mengalami miskonsepsi pada materi tersebut sebesar $80,11 \%$, dan setelah dilakukan remidiasi persentase miskonsepsi siswa berkurang menjadi $37,53 \%$.

\section{KESIMPULAN}

Berdasarkan hasil pengembangan instrumen tes diagnostik konsepsi lima tingkat pada materi Gerak Lurus beserta hasil uji validitas dan reliabilitas yang telah dilakukan dalam penelitian ini, maka instrumen tersebut telah dinyatakan valid dan reliabel sehingga layak untuk digunakan. Hasil uji coba terbatasnya juga membuktikan bahwa instrumen tersebut mampu menunjukkan tingkat pemahaman (level konsepsi) siswa pada materi Gerak Lurus dan karenanya instrumen tersebut dapat digunakan 
untuk mengidentifikasi level konsepsi yang sama pada siswa-siswa di tempat lainnya.

\section{DAFTAR PUSTAKA}

Adi dan Oktaviani. (2019). Faktor-Faktor Penyebab Miskonsepsi Siswa SD Pada Materi Life Processes And Living Things. Jurnal Profesi Pendidikan Dasar. 6, (1),91104.

Amin, Nasihun, Wiendartun, \& Samsudin A. (2016). Analisis Intrumen Tes Diagnostik Dynamic-Fluid Conceptual Change Inventory (DFCCI) Bentuk Four-Tier Test pada Beberapa SMA di Bandung Raya. Simposium Nasional Inovasi dan Pembelajaran. Prosiding SNIPS 2016.

Anam, Rif'at S., Widodo A., Sopandi W., \& Hsin-Kai Wu.(2019). Developing a fivetier diagnostic test to identify students' misconceptions in science: an example of the heat transfer concepts. Journal of Elementary Education Online, 18(3), 1014-1029.

Arikunto, S. (2013). Prosedur Penelitian Suatu Pendekatan Praktik: Edisi Revisi. Jakarta: PT. Rineka Cipta.

Bayuni, T. C., Sopandi, W., \& Sujana, A. (2018). Identification misconception of primary school teacher education students in changes of matters using a five-tier diagnostic test. Journal of Physics: Conference Series, 1013(1).

Dikmenli, M. (2010). Misconceptions of cell division held by student teachers in biology: A drawing analysis. Journal of Scientific Research and Essay, 5(2), 235247.

Fajriyyah \& Ermawati. (2020). The Validity And Reliability of Five-Tier Conception Diagnostic Test For Kinetic Theory Of Gases. Jurnal Inovasi Pendidikan Fisika. 9(2), 126-132.

Halliday \& Resnick. (2011). Fundamental of Physics. John Wiley \& Sons, Inc.

Jannah \& Ermawati. (2019). Identify 11th Grade of Senior High School Jogoroto students' misconceptions on Dynamic Rotation and Rigid Body Equilibrium concepts using Four-Tier Diagnostic Test. Journal of Physics: Conference Series, 1491(1).
Kaltakci-Gurel, D., Eryilmaz, A., \& McDermott, L. C. (2015). A Review and Comparison of Diagnostic Instruments to Identify Students' Misconceptions in Science. EURASIA Journal of Mathematics, Science \& Technology Education, 11(5), 989 - 1008.

Kirbulut \& Geban. (2014). Using Three-tier Diagnostic Test to Assess Students' Misconceptions of States of Matter. Eurasia Journal of Mathematics, Science and Technology Education. 509-521.

Köse, S. (2008). Diagnosing Student Misconceptions: Using Drawings as a Research Method. World Applied Science Journal, 3(2), 283-293.

Kurniawati \& Ermawati F.U. (2019). Analysis Students' Conception Using Four-Tier Diagnostic Test for Dynamic Fluid Concepts. Journal of Physics: Conference Series, 1491(1).

Pujianto Agus, Nurjannah, dan Darmadi, I Wayan. (2013). Analisis Konsepsi Siswa Pada Konsep Kinematika Gerak Lurus. Jurnal Pendidikan Fisika Tadaluko (JPFT). Vol 1, No.1.

Qonita \& Ermawati. (2020). The Validity and Reliability of Five Tier Diagnostic Test for Vector Conception. Jurnal Inovasi Pendidikan Fisika. 9(3), 459-465.

Riduwan \& Akdon. (2013). Rumus dan Data Dalam Analisis Statistika. Bandung: Alfabeta.

Salsabila \& Ermawati. (2020). Validity And Reliability Of Conception Diagnostic Test Using Five-Tier Format For Elasticity Concepts. Jurnal Inovasi Pendidikan Fisika. 9(2), 439-446.

Serway. (2004). Phyisics for Scientist and Engineers. New York: PearsonAddison Wesley.

Sudijono, A. (2014). Pengantar Statistik. Jakarta: Rajawali Pers.

Sugiyono. (2015). Metode Penelitian Pendidikan. Bandung: Alfabeta.

Tyndall, E. P. T. (2013). College Physics in Science. OpenStax College: Texas.

Yolanda, Yospin. (2017). Remidiasi Miskonsepsi Kinematika Gerak Lurus Dengan Pendekatan STAD. Science and Physics Education Journal (SPEJ). 1(1). 
Young \& Freedman. (2013). University Physics with Modern Physics 13th edition. New York: PearsonAddison Wesley. 